\title{
14. SOME ASPECTS OF PLATE TECTONICS IN THE ARABIAN SEA
}

\author{
Robert B. Whitmarsh, National Institute of Oceanography, Wormley, Godalming, Surrey, United Kingdom
}

\section{INTRODUCTION}

The sediments and underway data collected during Leg 23 , besides contributing to knowledge of the oceanic paleo-environment, also contribute to three specific aspects of the plate tectonics history of the Arabian Sea. These are the origin of the Laccadive-Chagos Ridge, the identification of magnetic anomalies and fracture zones in the Arabian Sea, and the origin of the sea floor between the Owen Fracture Zone and Arabia. These particular subjects are treated separately below.

\section{ORIGIN OF THE LACCADIVE-CHAGOS RIDGE}

The Laccadive-Chagos Ridge is a major linear feature on the floor of the Indian Ocean. The ridge extends a distance of $2200 \mathrm{~km}$ in a north-south direction, from the Laccadive Islands at $14^{\circ} \mathrm{N}$ to the Chagos Islands at $6^{\circ} \mathrm{S}$. The ridge is slightly arcuate being concave to the west. A considerable length of the crest of the ridge is composed of shoals, banks, coral reefs, and atolls at depths less than 1500 meters, and broadly these shoal areas are grouped as the Laccadive, Maldive, and Chagos islands. Between the shoals the water depth is commonly around 2000 meters and exceptionally reaches 4000 meters between the Maldive and Chagos islands. Site 219 was drilled in one such gap between Minicoy Island and the Laccadives. To the west of the ridge there is a relatively flat broad area of sea floor at about 4000 meters depth, around 500 meters above the adjacent abyssal plain, and it was on this platform that Site 220 was drilled. South of where it merges with the Indian continental slope, to about $3^{\circ} \mathrm{N}$, the east flank of the ridge is bounded by abyssal plain sediments at 2500 meters depth. These sediments are 1.5 to $2.5 \mathrm{~km}$ thick east of the Laccadive Islands (Eremenko, 1966). South of the equator a scarp is developed, which drops down to at least 4500 meters, with a parallel ridge and trough (the Chagos Trench) flanking the Chagos mass.

The ridge has been variously explained as a transition zone between the Indian continent and the ocean (Narain et al.,1968); as a fracture zone (McKenzie and Sclater, 1971); and as a hot-spot ridge (Francis and Shor, 1966; Morgan, 1972). Narain et al. believe the ridge is a transitional region simply because the crustal thickness determined by seismic refraction shooting (Francis and Shor, 1966) is intermediate between that normally found under continents and oceans. This argument is invalid because similar intermediate crustal thicknesses have been observed under a chain of volcanic islands in the central Pacific (Hill, 1969; Furumoto et al., 1971). Also, normal oceanic crustal structure and recognizable sea-floor spreading anomalies were found just east of Chagos Bank (Francis and Shor, 1966; McKenzie and Sclater, 1971). Thus, it seems impossible that the ridge represents a west to east transition between ocean and continent.
The arguments presented by McKenzie and Sclater (1971), that the ridge was built up over a transform fault during the early Tertiary pause in sea-floor spreading, are circumstantial. Their argument may be paraphrased as follows. Identical sea-floor spreading magnetic anomalies, attributable to the Heirtzler et al. (1968) time-scale of reversals, can be recognized both in the northwest Arabian Sea (around $15^{\circ} \mathrm{N}, 65^{\circ} \mathrm{E}$ ) and south of India (around $10^{\circ} \mathrm{S}$, $75^{\circ} \mathrm{E}$ ). These anomalies cannot be definitely identified in-between these two areas. The anomalies have an east-west trend and therefore a transform fault or faults must have existed to explain the almost $3000-\mathrm{km}$ right-handed offset of the anomalies. One right-handed transform fault of unknown offset and trend (named Anahita) can be postulated in the Arabian Sea. This transform fault may be parallel to the Laccadive-Chagos Ridge; if so, it supports the hypothesis that the Laccadive-Chagos Ridge was also a transform fault, a fault which must have had a very large offset. McKenzie and Sclater conclude their argument by pointing out the existence of two more right-handed fracture zones south of India (named Indira and Indrani). The strike of the Indira Fracture Zone, due north, is poorly determined but roughly parallels the Laccadive-Chagos Ridge. The strike of the Indrani Fracture Zone is indeterminate.

It seems to the present writer that one major condition that should be satisfied by the axis of the Laccadive-Chagos Ridge, if it was a transform fault, is that it should be "parallel" to the trace of the Owen Fracture Zone (i.e., the ridge and the Owen Fracture Zone should be on small circles about the same pole) since the latter was certainly an active transform in the Early Tertiary (see Whitmarsh et al., this volume). Clearly the ridge is not "parallel" to the Owen Fracture Zone. Further, careful study of a number of bathymetric and seismic reflection profiles obtained over the west flank of the Maldives reveals that there are a number of parallel north northeast sea-floor or subbottom scarps (Figure 1). A similarly trending deep trough exists at $7^{\circ} \mathrm{N}, 69^{\circ} 45^{\prime} \mathrm{E}$ in crust which is demonstrably of Eocene age (see next section). This trend intersects the north-south to $350^{\circ}$ axis of the Laccadive-Chagos Ridge at this lattitude. It is very likely that these scarps and the trough represent small fracture zones formed during the Early Tertiary sea-floor spreading. Thus, it appears that the LaccadiveChagos Ridge was not a transform fault in the Early Tertiary.

McKenzie and Sclater did not discuss the possibility that the large net offset of anomalies between the Arabian Sea and south of India could as well have been produced by a small number of fracture zones each with an offset of only some hundreds of kilometers. This explanation is favored by the writer and is expanded in the next section.

Thus, only the explanation of Morgan (1972) for the Laccadive-Chagos Ridge remains. His hypothesis is that 


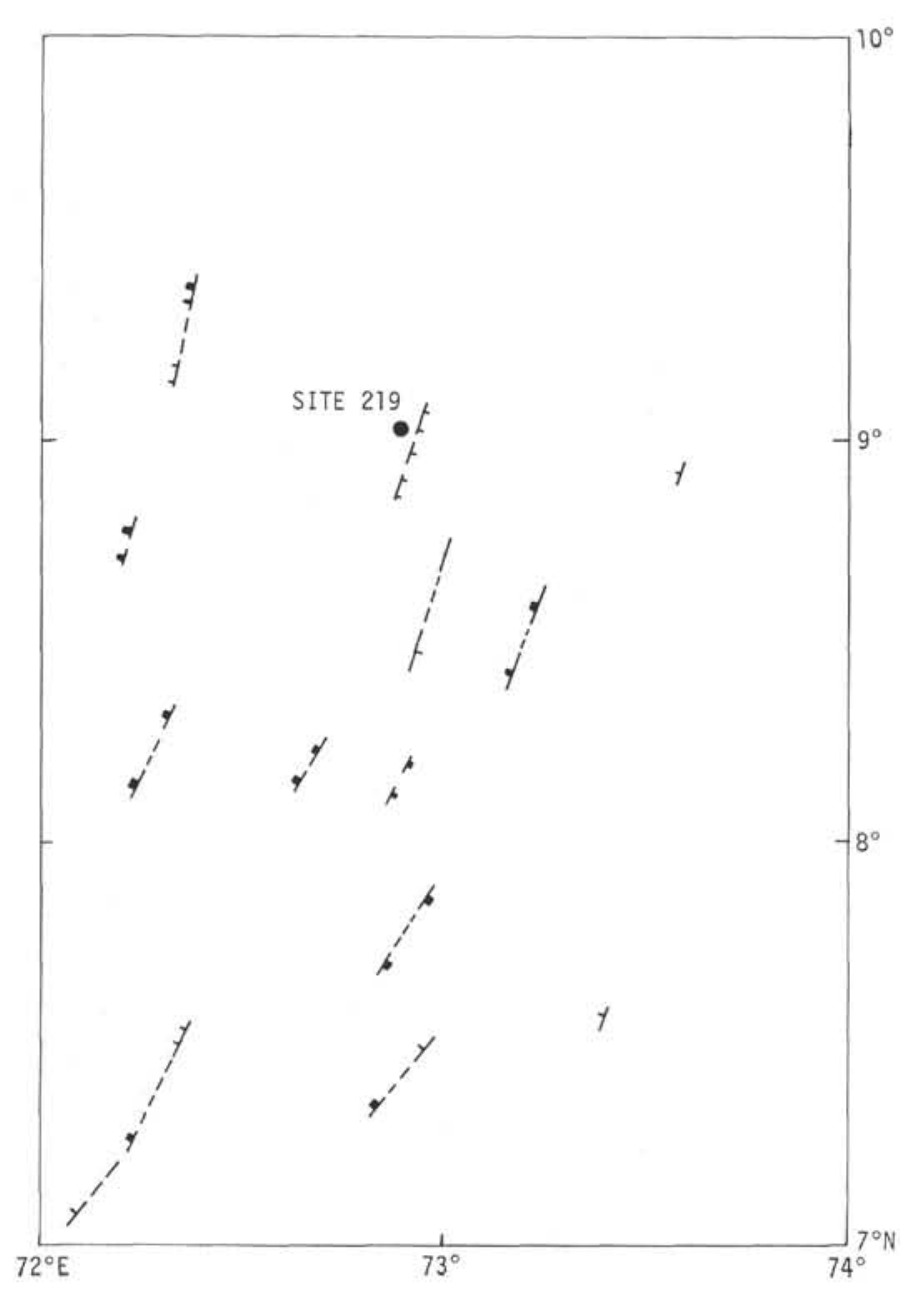

Figure 1. Sea-floor scarps deduced from collected soundings and from seismic reflection profiles obtained by Glomar Challenger, Conrad, and Oceanographer. Each long dash denotes one observation of a scarp with the square or line (soundings or reflection profile, respectively) denoting the side on which the scarp face lies. Short dashes represent interpolations between observations. Oceanographer data courtesy of N.O.A.A., Atlantic Oceanographic and Meterological Laboratories, Miami; Conrad data from cruise CONRAD-9, courtesy of the Lamont-Doherty Geological Observatory.

currently a hot-spot exists beneath the island of Reunion situated on the African plate. In the past the Madagascar plate has moved north-east, relative to the mantle, and consequently the Reunion-Nazareth Bank line of volcanic seamounts and islands was formed. During some period prior to the formation of the Central Indian Ocean ridge, and due to the northward drift of the Indian plate, the hot-spot lay successively beneath peninsular India (Deccan Traps), the Laccadives, the Maldives, and Chagos Bank, thus forming the Laccadive-Chagos Ridge. Francis and Shor (1966) favored the migration of volcanity in the opposite direction, but since their hypothesis does not take into account the Reunion-Nazareth Bank line, it is not pursued further here. If Morgan's hypothesis is correct then there should be a systematic decrease in age of volcanism along the Deccan Traps-Reunion line and a change in the rate of decrease corresponding (1) to the beginning and end of the static or very slow-spreading phase postulated by McKenzie and Sclater and (2) to the spreading ridge crossing the hot-spot, if the ridge was actively spreading at the time. All known ages are plotted in Figure 2. This figure shows both a systematic decrease in age of volcanism as well as a marked change in the rate of age decrease along the ridge at

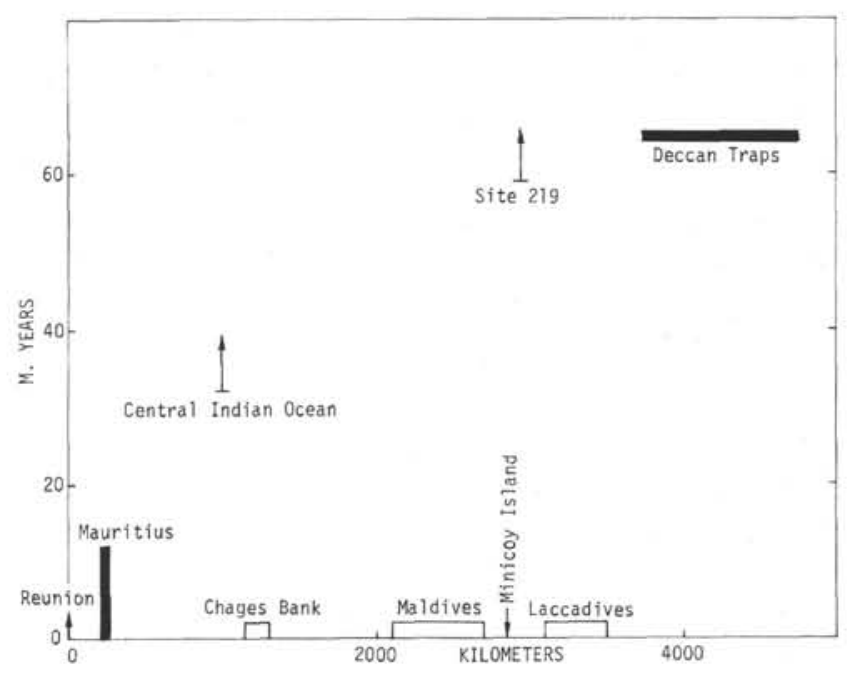

Figure 2. Plot of isotope ages and age estimates of the periods of volcanism along the Deccan Trap-Réunion hot-spot ridge. Deccan Trap age from Wellman and McElhinny (1970); Site 219 age is a minimum since igneous basement was not reached (see Chapter 3); the date at $1000 \mathrm{~km}$ is a minimum for the time when the spreading ridge crossed the hot-spot deduced from the oldest sediments overlying basalt at Site 238 at the foot of the Chagos Bank (Fisher et al., 1971); dates for Mauritius and Réunion from McDougall and Chamalaun (1969).

the point where the hot-spot passed under the spreading ridge. Thus, the evidence supports a hot-spot origin for the ridge. It also appears that the hot-spot crossed a spreading plate boundary before $32 \mathrm{~m} . y$. ago. The data are too scattered to resolve variations due to any period of nonspreading in the Early Tertiary.

A further line of evidence is provided by the subsidence history of Site 219. This site was under very shallow water in the Paleocene, and the sea floor began to sink in the Early Eocene. Total subsidence was of the order of 2100 meters, but there is no indication of when sinking ceased, or whether it still continues today. It can also be inferred from the coral atolls and reefs that the Chagos Bank, the Maldives, and a large part of the Laccadives were also close to sea level, if not subaerial, before the initiation of coral reef growth, and that the upward growth of the reefs has kept pace with subsequent subsidence. Thus there is good evidence that most of the foundation of the LaccadiveChagos Ridge was very close to sea-level at some stage. It is rare in the oceans that fracture zones have islands along them and unknown for long transform faults to have a chain of islands except in association with either a hot-spot 
(e.g., Azores, Macquarie Island) or with a fault-trench plate boundary (e.g., the Greater Antilles, South Georgia Island in the Scotia Sea). However, none of the above examples of islands on a transform fault are associated with pure transform motion, each fault has a component of extension or compression too, and it is doubtful whether a line of islands is ever produced along a pure transform fault.

In conclusion it is believed (1) that the Laccadive-Chagos Ridge was never the site of a pure transform fault; (2) that it is even unlikely that it was a transform fault with a component of extension because of the systematic age decrease along the ridge and nonparallelism with wellfounded fracture zones; (3) that the ridge is now the inactive and subsided part of a linear volcanic feature formed by the motion of the Indian plate over a mantle hot-spot now situated beneath the island of Reunion, and (4) that the Laccadive-Chagos Ridge does not represent a west to east transition from ocean to continent.

\section{MAGNETIC ANOMALIES AND FRACTURE ZONES IN THE ARABIAN SEA}

McKenzie and Sclater (1971) were unable to precisely determine the trends of any Early Tertiary fracture zones on the Indian plate in the Arabian Sea or in the region south of India. It is important to know such trends in order to determine an early Tertiary pole of rotation between India and Madagascar. These fracture zones no longer have bathymetric expression because they are covered by sediments. McKenzie and Sclater were working primarily with magnetic anomaly profiles, and such profiles cannot give strong constraints on the trends of fracture zones because the faults do not give rise to easily identifiable perturbations of the earth's magnetic field. During the early part of Leg 23 , we were working in a region where there were Lower/Middle Eocene cherts which could be easily mapped using seismic reflection profiles. It so happened also that the crust in this area was of Eocene age, and thus the Middle Eocene "isochron" was crossed at the point where the chert reflector intersected the igneous basement reflector on the seismic profiles. In practice the latter reflector was not visible when overlain by the chert, due to the high reflectivity of the chert, and so the "isochron" was recognized by the change from a smooth chert acoustic basement to a rough igneous basement. Using the seismic data of Glomar Challenger, Vema, and Conrad, as well as the bathymetric chart of Laughton, it was possible to identify two of the fracture zones shown in Figure 3. Following the convention of McKenzie and Sclater, whereby the names of Indian Ocean fracture zones are chosen from Indian mythology, the names Rudra and Shiva are proposed for these faults. The Rudra Fracture Zone has a well-determined trend because not only can it be identified on three seismic profiles, but also it has a sea-bed expression as a long narrow trough. The existence of the Rudra Fracture Zone is also implied by the age of the sediments overlying basement at Site 221 . These sediments are younger than those overlying basement at Site 220 which lies farther south. The Shiva Fracture Zone is only identified indirectly by the disappearance of the chert reflector and the resultant appearance of rough basement on the east to west Vema profile (Figure 3).
However, further constraints on the trend of the Shiva Fracture Zone and the existence of yet a third fracture zone (here called Brahma) are deduced from several magnetic profiles, including that of Glomar Challenger, not utilized by McKenzie and Sclater. These extra profiles were obtained from the compilation by D. H. Matthews for the I.I.O.E. Atlas. Further, assuming that the east-west anomaly trend persists across the Arabian Sea, the offsets of these fracture zones can be determined if the anomalies can be identified. Between the Anahita and the Shiva fracture zones, anomalies 25 to 27 are identified simply by visual comparison with profiles known to exhibit the same anomalies (McKenzie and Sclater, 1971) between the Owen and Anahita fracture zones. The situation between the Rudra and Shiva fracture zones is not so simple; however, here the approximately north-south track (i.e., perpendicular to the anomaly trends) of Glomar Challenger over Site 221 is of assistance.

This profile was projected onto a north-south line (Figure 4) and was compared with calculated anomaly profiles using spreading rates of $1.0,1.6,2.5,4$, and $6.5 \mathrm{~cm} / \mathrm{yr}$. Two constraints on fitting the calculated profiles were (1) the 46-m.y. micropaleontological age of the oldest sediments at Site 221 which indicated that the youngest possible anomaly over the site is anomaly 18 , and (2) the observation by McKenzie and Sclater that the spreading rate in the Arabian Sea just east of the Owen Fracture Zone for the period from just after anomaly 23 to anomaly 26 was $6.5 \mathrm{~cm} / \mathrm{yr}$. Thus only the fit shown in Figure 4 seems to be possible, and the large negative anomaly just north of the site is identified as anomaly 20 . The spreading rate appears to have changed from 6.5 to $2.5 \mathrm{~cm} / \mathrm{yr}$ at about the time of anomaly 23 . The only major discrepancy in the fit is that anomaly 19 is missing from the observed profile. It is unlikely that this anomaly was missed because of the discontinuity in the profile at Site 221 . Another difficulty with this identification is that anomalies 25 and 26 are not recognizable on three Owen profiles passing to the north of the site. In their place there are east-west-trending anomalies with shorter wavelengths. Nevertheless, the identification is accepted here because it also agrees with the only other long almost north-south magnetic profile in the Arabian Sea, that of Conrad-9 (Figure 4).

The trend of anomalies 18 to 22 has not been determined directly by correlations between profiles; however, it can confidently be estimated to be approximately east-west, and probably parallel to the older anomalies, for several reasons. First, anomaly 20 has been identified at two places at the same distance from anomaly 24 (Figure 4), and secondly east-west profiles intersecting the Conrad-9 and Glomar Challenger-23 tracks in the region of anomalies 18 to 22 have long wavelength anomalies indicating that the tracks are oriented roughly along the anomaly strike. Further, a line joining the points at which anomaly 20 has been recognized is not parallel to the present Carlsberg Ridge confirming that anomalies 18 to 22 have not been formed by the present phase of spreading.

Another result of the recognition of anomalies 18 to 22 in the Arabian Sea is that now the hiatus in spreading suggested by McKenzie and Sclater is seen to have been 


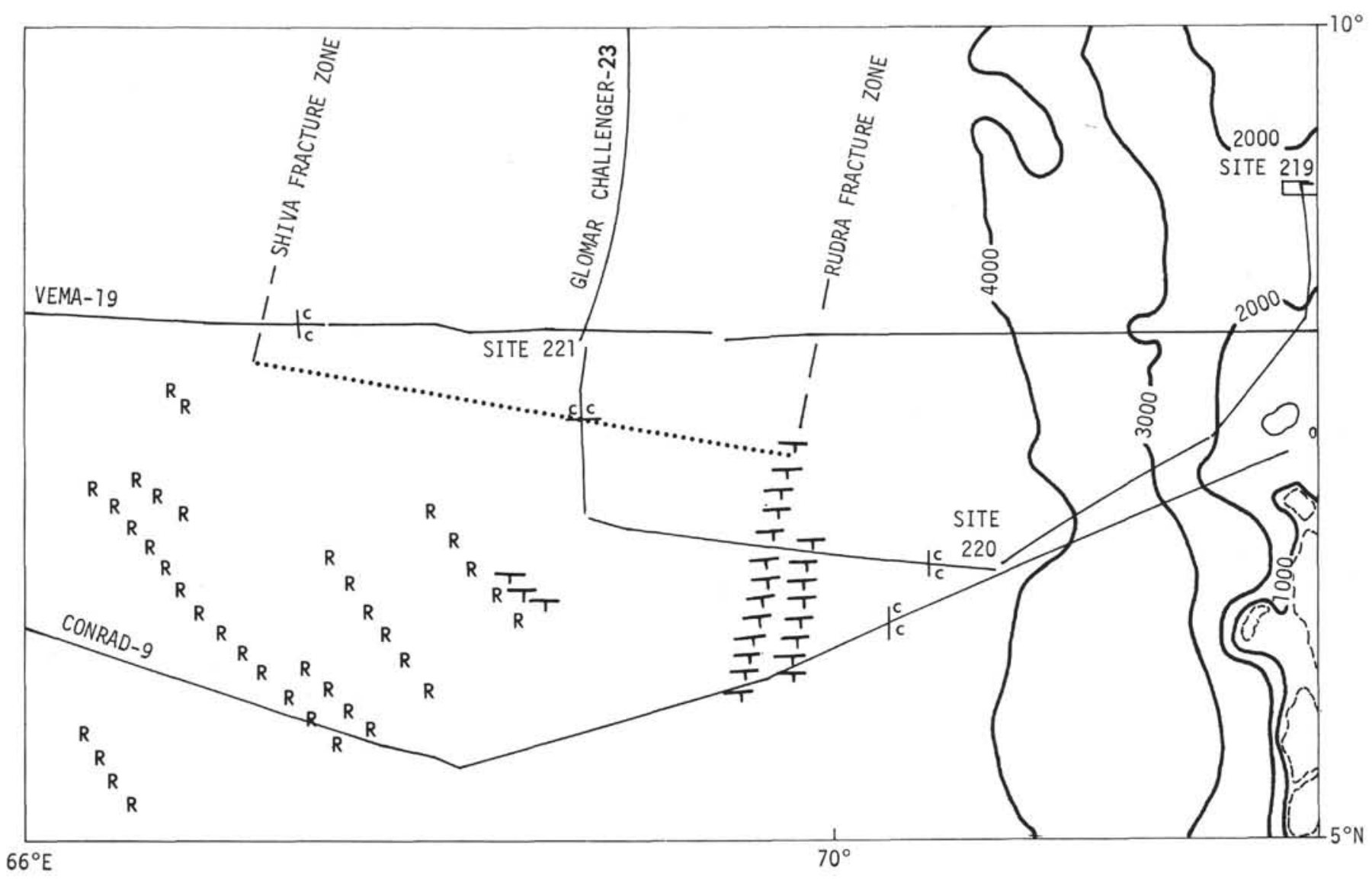

Figure 3. How the Rudra and Shiva fracture zones were recognized on the basis of bathymetry and reflection profiles. $R=$ ridge; $T=$ trough; $C$ denotes the region in which the smooth chert reflector merges with a rough igneous basement reflector, the $C$ is drawn on the smooth reflector side of the line; dots denote the Middle Eocene "isochron." Contoured bathymetry depths in meters in the east only, to show the extent of the Maldive Ridge from Laughton (unpublished). Vema-19 and Conrad-9 data courtesy of Lamont-Doherty Geological Observatory.

shorter than they predicted. The evidence here suggests it began no earlier than about $45 \mathrm{~m} . \mathrm{y}$. ago and therefore lasted no more than 10 m.y.

Accepting the fit proposed in Figure 4, it is possible to tentatively identify a large negative anomaly observed on Project Magnet profile 506 at $71^{\circ} \mathrm{E}$ as anomaly 20 (Figure 5). The basis for this identification is the 5.5-m.y. age difference between the oldest sediments at Sites 220 and 221 and a north-south spreading rate of $2.5 \mathrm{~cm} / \mathrm{yr}$. Thus, the position of anomaly 20 south of Site 220 can be predicted and this coincides with the observed negative anomaly.

In conclusion, therefore, the early Tertiary sea-floor spreading in the Arabian Sea persisted until at least anomaly 18 time with a change of rate about the time of anomaly 23 , and three new fracture zones are identified east of the Owen Fracture Zone. These faults offset anomalies 18 to 29 in a right-handed sense, although the older anomalies have yet to be identified in the southeast Arabian Sea. The fracture zones are responsible for a total offset of the magnetic anomalies of $600 \mathrm{~km}$. This figure is only a fifth of the observed $3000-\mathrm{km}$ offset, and therefore a large fracture zone or zones with an offset of $2400 \mathrm{~km}$ must exist east of Site 220 and west of $10.5^{\circ} \mathrm{S}, 74^{\circ} \mathrm{E}$ where anomaly 25 can be identified (McKenzie and Sclater, 1971). Although part of such fracture zones may now be covered by the Maldive Islands, it appears quite possible that the 1200-km-long scarp and ridge east of the Chagos Archipelago represents a fracture zone of the above system since this feature lies parallel to the well-determined trends of the Rudra and Shiva fracture zones (Figure 5). The name Vishnu is suggested for this fault. A constraint on any proposed pattern of fracture zones under the LaccadiveChagos Ridge is that everywhere the onset of volcanism along the ridge, as predicted by Figure 2, should occur at a later date than the age of formation of the ocean crust beneath.

\section{ORIGIN OF THE REGION BETWEEN ARABIA AND THE OWEN FRACTURE ZONE}

The ocean crust between Arabia and the Owen Fracture Zone has a character altogether different from the ocean basin to the east. Over this 240 to $400-\mathrm{km}$-wide strip no large magnetic anomalies are observed, and with the available data no linear magnetic trends can be discerned. The average sediment thickness may be considerable since only exceptionally is acoustic basement seen on seismic profiler records, although seismic penetrations of up to $1 \sec (900$ meters) have been achieved.

In the early Tertiary the Owen Fracture Zone is believed to have represented part of the plate boundary (as a sinistral transform fault) between India and Somalia-Arabia during the northward drift of the former, which has been 


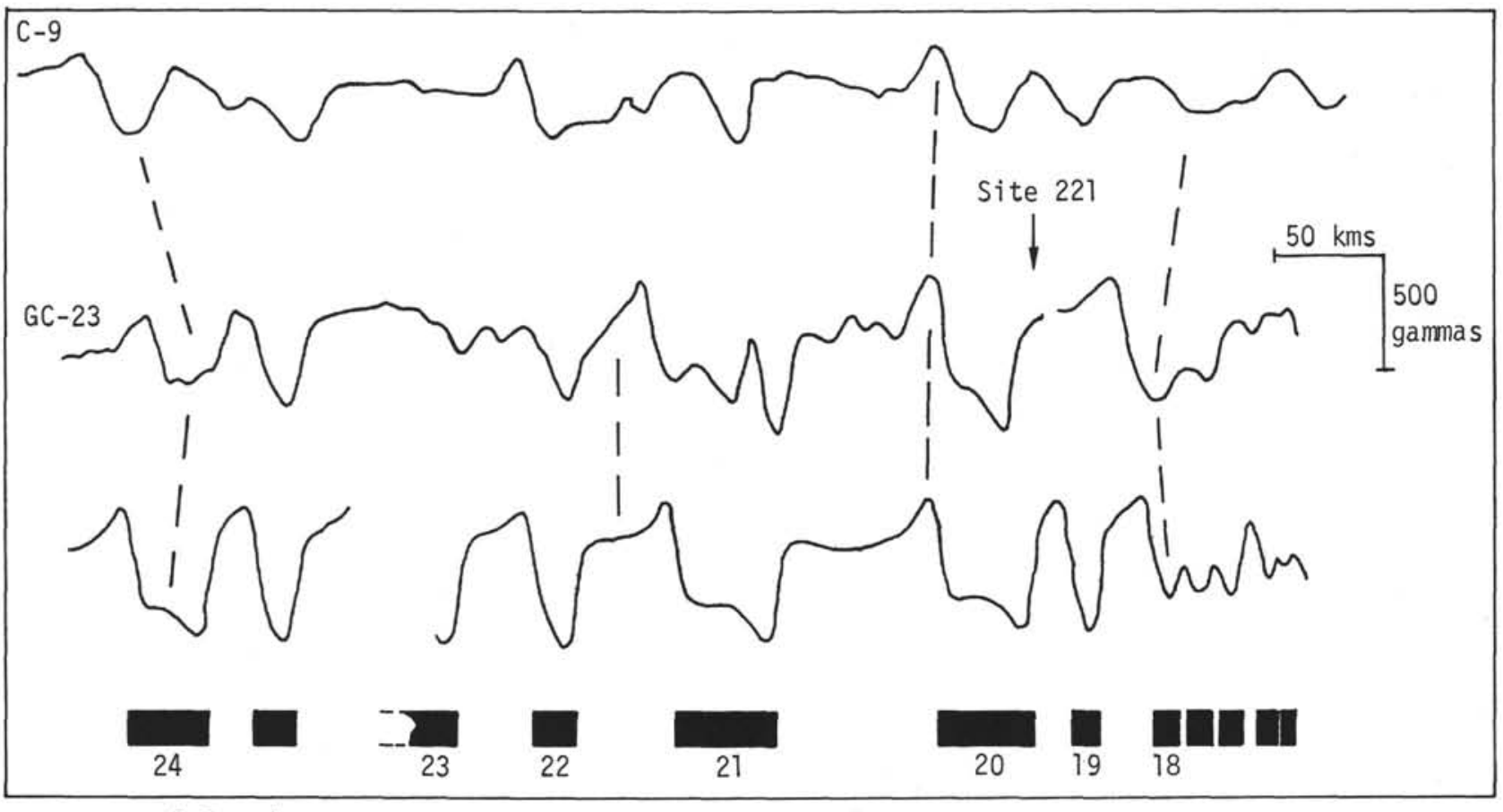

NORTH

$2.5 \mathrm{~cm} / \mathrm{yr}$

Figure 4. Upper and middle curves are the magnetic anomaly profiles (for track see Figure 5) observed by Conrad-9 and Glomar Challenger projected onto a north-south line. The lowermost profile is a synthetic profile generated by a ridge striking $105^{\circ}$ at $13^{\circ} \mathrm{S}$ but observed at $8^{\circ} \mathrm{N}, 68^{\circ} \mathrm{E}$ with a magnetic strike of $090^{\circ}$. The magnetic layer lay between 5 and 7 $\mathrm{km}$ below sea level. Periods of normal polarity are numbered according to the scheme of Heirtzler et al. (1968). The spreading rates are indicated beneath the modal. Conrad-9 data courtesy of Lamont-Doherty Geological Observatory.

recognized from paleomagnetic measurements (McElhinny, 1970). This hypothesis concerning the Owen Fracture Zone is suggested by the lack of recognizable magnetic anomalies on the flanks of the Sheba Ridge older than the opening of the Gulf of Aden and has been substantiated by paleomagnetic measurements on Glomar Challenger cores (see Whitmarsh et al., this volume). Gabbro dredged from the southern end of the Owen Fracture Zone (Chain Ridge) has been dated radiometrically at 89.6 m.y. (Bunce et al., 1967). Farther south, and west of the extrapolated trend of the Chain Ridge, Glomar Challenger has cored Middle Cretaceous (Turonian/Cenomanian) sediments on the Kenya continental rise without reaching basement (Simpson et al., 1972). Thus, in all likelihood the Arabian continental margin west of the Owen Fracture Zone has a similar age. This would be consistent with the lack of large magnetic anomalies, if indeed the crust here was formed by sea-floor spreading, because of the long normal polarity interval from 80 to 110 m.y. (Helsey and Steiner, 1969), and with the thick sediments. However, the lack of anomalies could be due to other reasons such as the depth of burial of the basaltic layer.

Igneous rocks of unusual petrology for oceanic areas have been dredged or cored along the Owen Fracture Zone. They include spilitic basalt and microdiorite (Barker, 1966), gabbro (Bunce et al., 1967), trachybasalt (Site 223, Chapter 7), and lamprophyre (Site 224, Chapter 8). It is likely that the unusual petrology of these rocks is due to their proximity to a transform fault and does not indicate a widespread region of anomalous rocks west of the Owen Fracture Zone. The same explanation was put forward by Cann and Vine (1966) to explain the presence of gabbro, spilites, and quartz breccias in dredge hauls recovered near the crest of the Carlsberg Ridge. The igneous rocks recovered at Sites 223 and 224 are apparently extrusive. If they are assumed to be slightly older than the overlying sediments, then these rocks are younger, perhaps by about 10 m.y. according to the magnetic anomalies, than the normal oceanic crust to the east. They are also, on this assumption, considerably younger than the 90-m.y.-old gabbro collected by Bunce et al.

There are two possible models of Late Cretaceous/Early Tertiary sea-floor spreading involving the Owen Fracture Zone (Figure 6). One of these involves three plates and the other only two. The three-plate model is favored by McElhinny (1970) because it best fits paleomagnetic data from Africa, Madagascar, and India. The poles of India and Madagascar were very close in the Late Cretaceous suggesting that these two areas were in proximity up to 70 or 80 m.y. ago. McElhinny postulates that India and Madagascar separated at about the end of the Cretaceous; however, the 90-m.y. gabbro of Bunce et al. (1967) may indicate that the southern part of the Owen Fracture Zone was active at a considerably earlier date. The second model is that used by McKenzie and Sclater (e.g., their Fig. 47). In this model the spreading ridge migrates northward with 


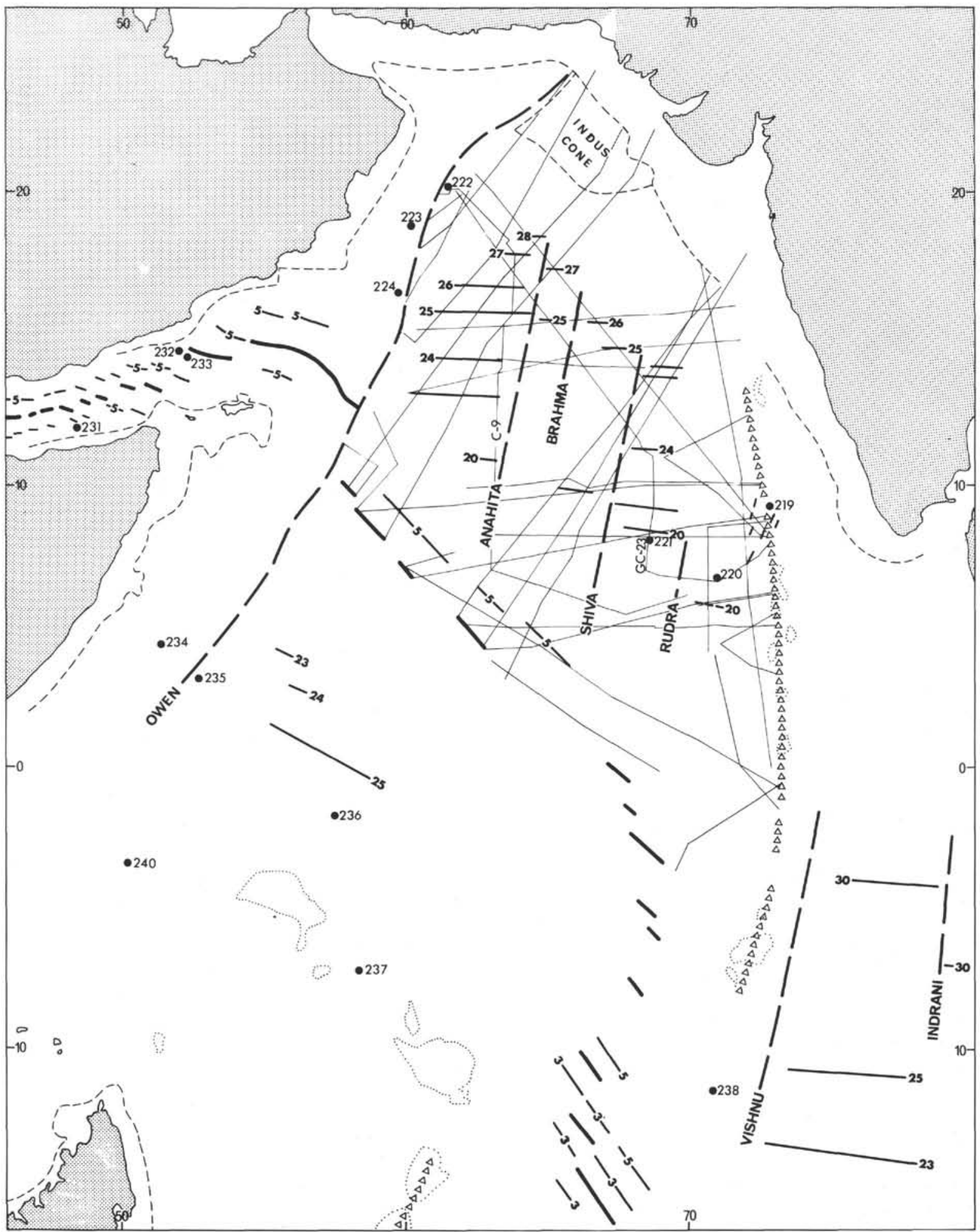

Figure 5. Fracture zones and magnetic anomalies of the northwestern Indian Ocean west of $80^{\circ} E$. The identification of newly discovered fracture zones and anomalies is discussed in the text. Unnumbered anomalies have not been related to the Heirtzler system, but are included because they have trends determined by correlations between profiles. The features of Figure 1 have been added around Site 219. Note particularly how the axis of the Laccadive-Chagos Ridge (triangles) is not parallel to the Owen Fracture Zone, nor to any other of the fracture zones shown. Based on data of Laughton et al. (1970), McKenzie and Sclater (1971), Fisher et al. (1971), and the unpublished compilation of Matthews for the I.I.O.E. Atlas. 200-meter contour (dotted) around islands; foot of continental slope (dashed line) indicated off continents. 


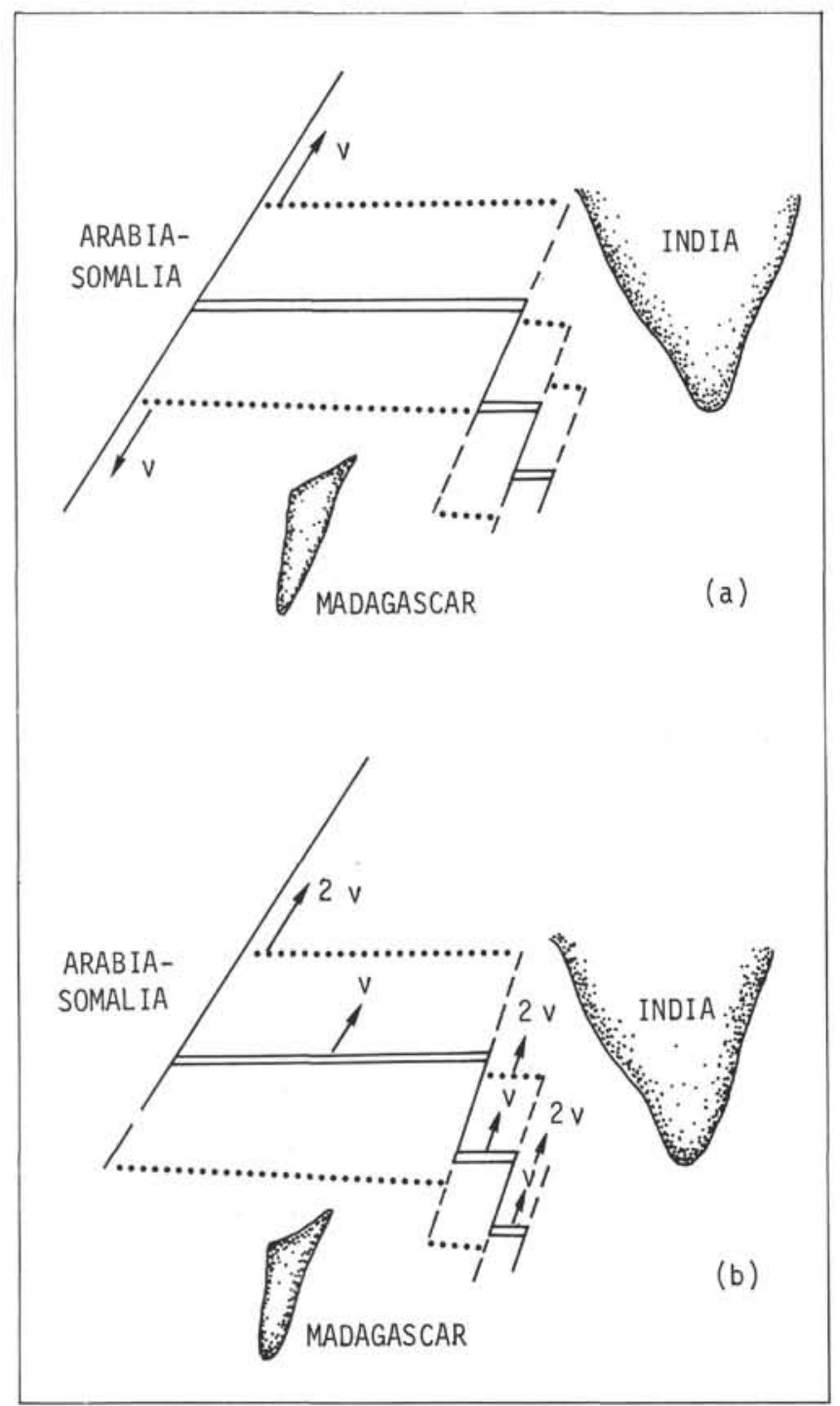

Figure 6. Two models of early Tertiary plate motion in the Arabian Sea; (a) 3-plate model; (b) 2-plate model. Arrows denote motion relative to Arabia-Somalia which is considered fixed. Dashed lines represent inactive fracture zones; single and double lines are transform faults and ridge axes, respectively.

respect to Africa, whereas India and the anomalies north of the ridge move at twice the speed of the ridge. This model is favored by the Leg 23 paleomagnetic results for the Early Tertiary which indicate a northward shift of India at $26 \mathrm{~cm} / \mathrm{yr}$ because this figure is closer to twice the spreading rate of $6.5 \mathrm{~cm} / \mathrm{yr}$ observed by McKenzie and Sclater.

It is now well proven that the Gulf of Aden began to open during or just before the earliest Miocene, i.e., some 22.5 m.y. ago (Fisher et al., 1972). The oldest magnetic anomaly which has been recognized in the Gulf of Aden is the 10-m.y. old anomaly 5 . Landward of this anomaly there are no large or distinctive anomalies in the area west of the Alula-Fartak Trench possibly because of the influence of the nearby continental margin. East of the Alula-Fartak Trench the continental margin is more distant, and in an attempt to find the boundary on the north flank of the
Sheba Ridge between the crust generated during the opening of the Gulf of Aden and the older pre-existing crust to the northeast, magnetic anomaly profiles across this region were studied. No clear-cut correlations between profiles, or between observed and calculated anomaly profiles, were discerned beyond anomaly 5 . On the other hand, there is a general tendency for the amplitude of the magnetic anomalies to decrease at about $80 \mathrm{~km}$ beyond anomaly 5 (as can be seen in Figure 7) between $55^{\circ}$ and $57^{\circ} 30^{\prime} \mathrm{E}$. This change in amplitude corresponds approximately to the line of the initial break inferred from McKenzie et al. (1970) by rotating the axial anomaly about their pole through half the angle required to close the Gulf of Aden at the 500-fathom contour. Glomar Challenger crossed this region, but the seismic profile does not show any rapid changes in character although the sediments to the east of the deepest part of the profile, which is a small abyssal plain, are markedly thicker than to the west. It is probably significant too that the deepest part of the sea floor, here encompassed by the 4000 -meter contour, runs very close to the McKenzie et al. line (Figure 7). Thus, the available field evidence is not inconsistent with the rotation angle and pole proposed by McKenzie et al. Although if the spreading rate of $1.2 \mathrm{~cm} / \mathrm{yr}$ for the last 10 m.y. (Laughton et al., 1971) is extrapolated to the preceding period of opening of the Gulf of Aden, which may be supposed to be represented by $80 \mathrm{~km}$ of sea floor, then the predicted date of separation of Somalia and Arabia is about 17 m.y. ago, about 5 m.y. too late for consistency with Site 231 in the central Gulf of Aden.

\section{REFERENCES}

Barker, P. F., 1966. A reconnaissance survey of the Murray Ridge: Phil. Trans. Roy. Soc. London, Series A, v. 259, p. 187-197.

Bunce, E. T., Langseth, M. G., Chase, R. L., and Ewing, M., 1967. Structure of the western Somali Basin: J. Geophys. Res., v. 72, p. 2547-2555.

Cann, J. R. and Vine, F. J., 1966. An area on the crest of the Carlsberg Ridge - petrology and magnetics: Phil. Trans. Roy. Soc. London, Series A, v. 259, p. 198.

Eremenko, N. A., 1966. The tectonics and petroleum possibilities of the southern part of India: Oil Natural Gas Commission Bull. v. 3, p. 371-376.

Fisher, R. L., Bunce, E. T., Cernock, P. J., Clegg, D. C., Cronan, D. S., Damiani, V. V., Dmitriev, L., Kinsman, D. J. J., Roth, P. H., Thiede, J., and Vincent, E. S., 1972. Deep Sea Drilling Project in Dodoland: Geotimes, September, v. 17, p. 17-21.

Fisher, R. L., Sclater, J. G., and McKenzie, D. P., 1971. Evolution of the Central Indian Ridge, Western Indian Ocean: Geol. Soc. Am. Bull., v. 82, p. 553-562.

Francis, T. J. G. and Shor, G. G., 1966. Seismic refraction measurements in the northwest Indian Ocean: J. Geophys. Res., v. 71, p. 427-449.

Furumoto, A. S., Campbell, J. F., and Hussong, D. M., 1971. Seismic refraction surveys along the Hawaiian Ridge, Kauai to Midway Island: Seismol. Soc. Am. Bull., v. 61, p. 147-166.

Heirtzler, J. R., Dickson, G. E., Herron, E. M., Pitman, W. C., and LePichon, X., 1968. Marine magnetic anomalies, geomagneitc field reversals and motions of the ocean floor and continents: J. Geophys. Res., v. 73, p. 2119-2136. 


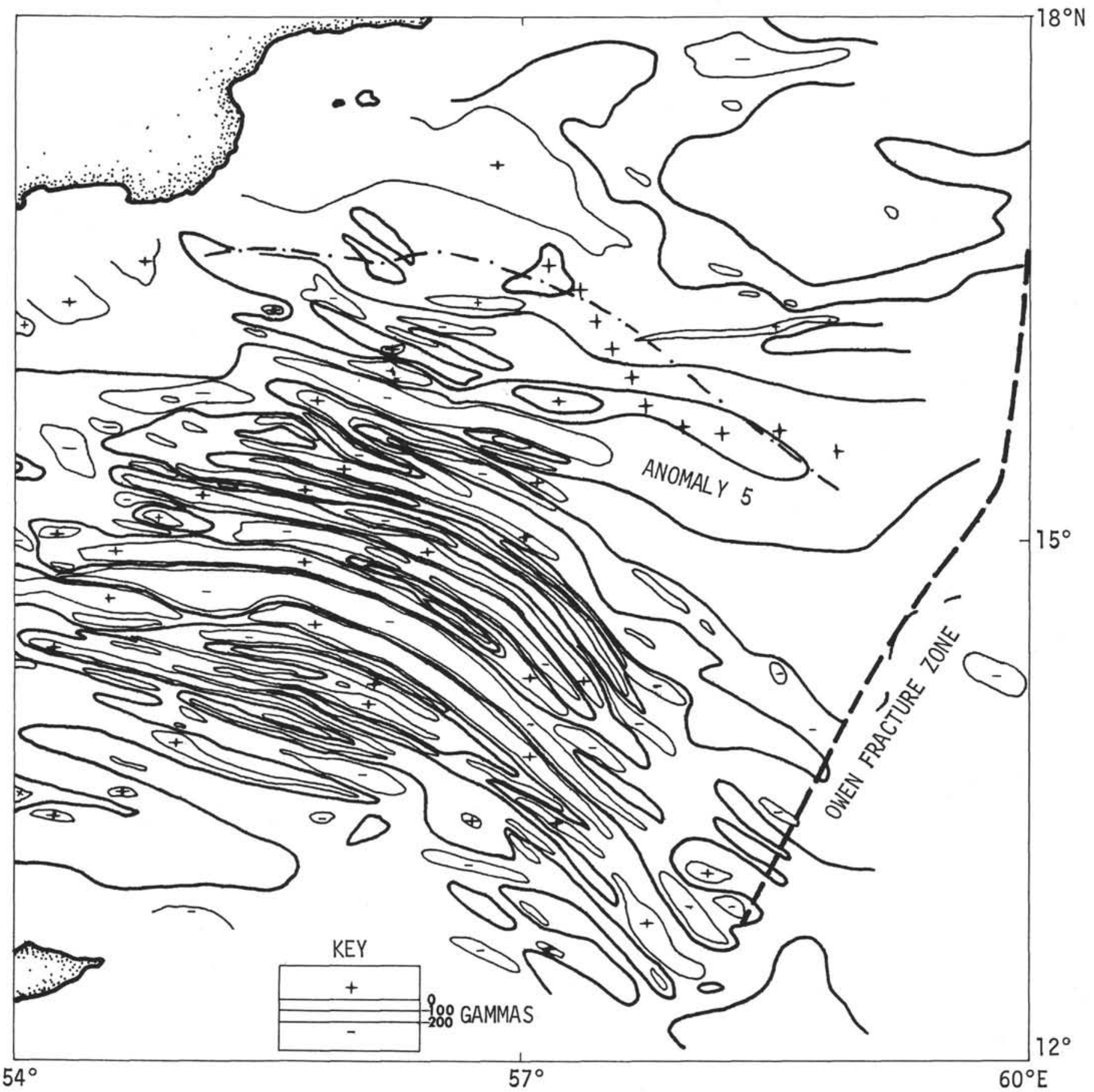

Figure 7. Magnetic anomaly contours over the Sheba Ridge after Whitmarsh in Laughton et al. (1970) but with Glomar Challenger-23 data added. The dash-dot line is the predicted boundary between pre-Gulf of Aden and post-Gulf of Aden crust after McKenzie et al. (1970). The line of crosses marks the median line between the 4000-meter contours enclosing the deepest water. For clarity, contours outside the range 0 to -200 gammas have been omitted. 
Helsey, C. E. and Steiner, M. B., 1969. Evidence for long intervals of normal polarity during the Cretaceous period: Earth Planet. Sci. Lett., v. 5, p. 325-332.

Hill, D. P., 1969. Crustal structure of the island of Hawaii from seismic refraction measurements: Seismol. Soc. Am. Bull., v. 59, p. 101-130.

Laughton, A. S., Whitmarsh, R. B., and Jones, M. T., 1970. The evolution of the Gulf of Aden: Phil. Trans. Roy. Soc. London, Series A, v. 267, p. 227-266.

McDougall, I. and Chamalaun, F. H., 1969. Isotopic dating and geomagnetic polarity studies on volcanic rocks from Mauritius, Indian Ocean: Geol. Soc. Am. Bull., v. 80, p. 1419-1442.

McElhinny, M. W., 1970. Formation of the Indian Ocean: Nature, v. 228, p. 977-979.

McKenzie, D. P., Davies, D., and Molnar, P., 1970. Plate tectonics of the Red Sea and East Africa: Nature, v. 226, p. 243-248.
McKenzie, D. P. and Sclater, J. G., 1971. The evolution of the Indian Ocean since the late Cretaceous: Geophys. J. R.A.S., v. 25 , p. 437-528.

Morgan, W. J., 1972. Deep mantle convection plumes and plate motions: Am. Assoc. Petrol. Geol. Bull., v. 56, p. 203-213.

Narain, H., Kaila, K. L., and Verma, R. K., 1968 , Continental margins of India: Canadian J. Earth Sci., v. 5, p. 1051-1065.

Simpson, E. S. W., Schlich, R., Leclaire, L., Girdley, W. A., Moore, C., White, S., Vallier, T. L., Muller, C., Zobel, B., Sigal, J., Gieskes, J., and Marshall, B. V., 1972. Leg 25, DSDP Western Indian Ocean, Geotimes, v. 17, p. 21-24.

Wellman, P, and McElhinny, M. W., 1970. K-Ar age of the Deccan Traps, India: Nature, v. 227 , p. 595-596. 